\title{
GENDER DIVERSITY ON BOARD AND ITS RELEVANCE TO FIRM PERFORMANCE: A STUDY ON PHARMACEUTICAL INDUSTRY OF BANGLADESH
}

\author{
Hossain Ahmmed Fahad \\ Post-Graduate \\ Faculty of Business Studies \\ University of Dhaka, Dhaka, Bangladesh \\ E-mail: Fahadhossain.frg@gmail.com \\ (iDhttps://orcid.org/0000-0002-1004-8660 \\ Imran Mahmud \\ Post-Graduate \\ Faculty of Business Studies \\ University of Dhaka, Dhaka, Bangladesh \\ E-mail: Imran.mahmud.du@gmail.com \\ Dhttps://orcid.org/0000-0002-9255-462X \\ Atkia Nabiha Rahman \\ Post-Graduate \\ Faculty of Business Studies \\ University of Dhaka, Dhaka, Bangladesh \\ E-mail: A.nabiharahman@gmail.com \\ (D)https://orcid.org/0000-0002-9961-164X
}

Received: September 23, 2021

Accepted: November 12, $2021 \quad$ Online Published: January 01, 2022

DOI: 10.46281/asfbr.v6i1.1520

URL: https://doi.org/10.46281/asfbr.v6i1.1520

\begin{abstract}
The study tries to examine the relationship between gender diversity on the Board and firms' profitability in Bangladesh's Pharmaceutical industry. The study employs a panel data approach with all the Pharmaceutical companies listed under Dhaka Stock Exchanges. The sample period covers eight years from 2012-2019. To conduct the study, Return on Equity and Tobin's $Q$ was taken as a proxy of accounting measure of profitability and market measure of profitability, respectively. The proportion of women on board structure was taken as a proxy for gender diversity. Some other variables: board size, firm age, leverage, and firm size, were incorporated to control the effect of these variables on profitability. The study reveals that gender diversity shows a positive but insignificant relationship with the firm's performance in terms of ROE. The $R$ square of this model was $11.67 \%$. In terms of Tobin's $Q$, gender diversity exhibited a significant positive relationship with firm performance. The $R$ square of this model was $17 \%$. This implies
\end{abstract}


that the market ascribes a great value to the inclusion of women in board structure since it increases the board structure's independence and profitability.

Keywords: Gender Diversity, Profitability, Board, Pharmaceutical Sector, Bangladesh.

JEL Classification Codes: C12, F65, L25.

\section{INTRODUCTION}

Bangladesh is among the few countries in South Asia that have increased women's employment and cut the wage gap between men and women in the past decade. But women still have limited choices, decision-making power in the jobs and economic environment. The Board of Directors is the internal mechanism of a company. Increased involvement of women on Board is said to increase transparency, accountability in the company. Women on Board can mitigate fraudulent activities and ensure the protection of investors' capital. So, women on Board may improve the financial health of a company.

Many companies failed in the past two decades due to a lack of good governance, poor accountability, earnings management, asset revaluation, and the use of creative accounting, etc. The company's Board of directors is responsible for setting up strategic plans that outline the corporation's growth path and sustainability. Hence, it is essential to investigate the board characteristic and diversity as these can significantly influence the company's performance.

Various empirical studies have been conducted worldwide, but the studies conducted in Bangladesh regarding this are pretty minimal if compared. A similar study was conducted on DSElisted seven pharmaceutical companies in Bangladesh using ROE, ROA, and NAVPS to measure financial performance (Islam, 2018). Another study used 259 listed companies in Bangladesh (Munira, 2020). Both found a positive association between women's representation in the boardroom and firm financial performance indicators. Where one study focused on a few companies of pharmaceutical sectors of Bangladesh, the other study looked into all the industries but for the years 2018 and 2019. These two studies do not provide a clear look at the actual state of a sector like pharmaceutical in terms of gender diversity.

This report studied the effects of gender diversity in the Board of directors on the profitability of the pharmaceutical industry in Bangladesh. Firm size, Firm Age, Board Size, DebtAsset Ratio, and Gender Diversity on Board were considered independent variables. ROA and Tobin's Q as the dependent variable.

\section{LITERATURE REVIEW}

Gender diversity on the board structure of companies began to beg the question of the interplay among the firm performance and women participation on the Board. The presence of multiple schools of thought has shown varieties of supports regarding this argument. Hambrick and Mason (1984) have established a negative relationship between firm performance and women's participation. The contrary has also been found.

Diversity has been viewed under agency theory as a measure of independence and a source of fair and transparent decision-making (Jensen \& Meckling, 1976; Luoma \& Goodstein,1999). Some have found proof of a lower degree of fraudulent activities for increased participation of women in corporate board structure. However, the degree to which increased participation of women will contribute to good corporate governance lies in what goal corporate governance should try to achieve. Brown et al. (2002) contemplated that women's participation would not 
contribute to the enhanced value of a firm if the existence of corporate governance does not promote performance improvement of the firm. As good corporate governance and an increase in women's participation on Board is essential for enhanced performance for a company, many countries have made it a compulsory requirement for the Board to have a high percentage of women composition. Norwegian companies were required to have $40 \%$ of their board members be represented by women (Huse, 2007).

Previous literature has shown that female participation on board increase firm performance. A positive impact on firm performance was found for Fortune 500 companies that incorporated at least three women on board structures from 2004-2008. (Joy et al., 2008). MSCI World Index reported that companies under the strong leadership of women had higher annual financial returns (11.1\% versus $7.4 \%)$ and price-to-book ratios (1.76 versus 1.56$)$ compared to companies with no such leadership of women (Lee et al., 2015).

With the introduction of control variables in this trajectory, somewhat ambiguous results have been found underlying the actual link between gender diversity and firm performance. Adams and Ferreira (2009) found that gender diversity among board members could produce poor firm performance. This result was inconsistent with previous literature. Another study on Nigerian firms with 122 samples and for the period 1991-2008 found a negative relationship between gender diversity and firm performance (Ujunwa, 2012). A 2014 study in the Economic Journal found no evidence to support the link between gender diversity in companies in the U.K. and corporate performance. The study concluded that gender diversity should be structured around the morals of variety. (Gregory et al., 2014)

But not all studies showed such results, even with the introduction of control variables. Nguyen et al. (2015), using a sample of 120 publicly listed companies as the sample for 2008 to 2011, found a positive relation between board gender diversity and firm performance. This study also added that the inclusion of more women on the Board increased firms' performances.

Moreover, using 638 American Fortune 1000 companies as a sample, Carter et al. (2003) found a significant positive correlation. In this study, company size, sector, and corporate governance characteristics were considered as control variables. A similar result was found in Erhardt et al. (2003) study, which examined the Return on Investment of 127 large U.S. companies with their proportion of women and minorities involved on the Board for 1993 and 1998. Evidence of such a link between the increase in the presence of women on Board and enhanced performance of firms was also found in Romanian companies (Ionascu et al., 2018). This study was conducted during 2012-2016 on the companies listed on Bucharest Stock Exchange.

In Bangladesh, Islam (2018) conducted a study on seven listed companies of the Dhaka Stock Exchange under the pharmaceutical sector. The study concluded that the companies should include trained and mature women on Board to increase shareholder value. Further research was done considering 259 listed companies in DSE for the years 2018 and 2019. This study also found a positive association. Despite the result of these two studies being positive, the studies were not conclusive enough.

\section{RESEARCH QUESTION}

Is gender-diverse boards of directors relevant to the financial performance of pharmaceutical companies listed in DSE? 


\section{Sample Selection}

\section{METHOD}

The population for this study comprised all companies listed in the pharmaceutical sector of DSE in the last eight years (2012-2019). The sample consists of companies, of which all the data for those years was available. Thus, the number of companies came down from 31 to 27 . All the relevant data were collected from secondary sources; these involve mainly the audited financial statements and the web portals of the selected companies.

\section{Variables Selection}

Following some literature (Vafaei et al., 2015; Haslam et al., 2010; Ionascu et al., 2018), marketbased and accounting-based variables have been selected to enhance the viability. For marketbased variables, Tobin's Q (Sá et al., 2017) has been chosen, as it is expected to capture the current and future outlook of the company. Return on Asset has been selected as an accounting-based variable as it is told to state a company's present and recent past performance adequately.

\section{Dependent Variables}

Return on Asset (ROA): ROA is a better estimation of profitability considering financial leverage. (Rezina et al, 2020; Munira, 2020; Ionascu et al, 2018) If a company can secure a higher ROA, it is utilizing its Asset more efficiently. ROA is calculated as net income divided by total assets.

Tobin's Q: Tobin's Q (Sá et al., 2017) has been selected for the market-based variable. Tobin's Q equals the summation of Market Value of Equity, Total Debt, and Preferred Share by Total Asset. It captures the current and future outlook of the company.

\section{Independent Variables}

Diversity: The proportion of women on the Board was used to measure diversity; this was selected as the primary independent variable, whose effect is the study's primary concern. It is calculated as the number of female board members divided by the number of total board members in a given year. (Vafaei et al, 2015; Haslam et al, 2010; Ionascu et al, 2018). A study investigated 259 listed companies on DSE and found a positive association between women's representation in the boardroom and firm financial performance indicators. (Munira, 2020). Meca et al. (2015) studied the link between boards' gender diversity and bank performance on a sample of 159 banks across nine countries for 2004-2010. The study showed that banks' performance is improved by gender diversity. Another study found that gender diversity among board members could result in poor firm performance. (Adams \& Ferreira, 2009)

Firm Size: Firm Size has been calculated using the literature of Asimakopoulus et al. (2009), Nunes et al. (2009), Pratheepan (2014), and Nakatani (2019). They found firm's size has a positive influence on a firm's performance. It is calculated as the Natural Log of Total Asset. It is one of the control variables of the study. Some researchers also found a negative relationship between a firm's size and firm's performance (Goddard et al. 2005)

Firm Age: Firm age has been calculated following Rezina et al. (2020). Blažková and Dvouletý (2019) found positive relationships between the firm's age and the firm's performance. On the other hand, some researchers found the relation was negative (Coad et al., 2013). The calculation method is: Natural Log of Firm Age (difference between the year of incorporation and time $\mathrm{t}$ )

Board members: It is calculated as a Natural Log of Board Size. Board members are expected to protect the interest of the investors via mediating any conflicts that arise. Thus, 
enhancing the firm's performance. While agency theory and resource dependency theory suggest that the board size positively affects performance, stewardship theory favors smaller board size and argues that larger board size negatively impacts firm performance. A study was carried out for five years from 2008 to 2012 using 145 non-financial companies listed in the NSE CNX 200 Index of India, which found that board size and the firm performance had a positive relation. (Kalsie \& Shrivastav, 2016).

Leverage: The leverage of the firm is measured as the Debt-Asset ratio. Leverage and a firm's performance are negatively related. (Asimakopoulus et al., 2009). Most empirical studies have found an inverse leverage-profitability relationship.

Table 1. Definition of Variables Used in Study

\begin{tabular}{|l|c|c|c|}
\hline Variable & Notation & Expected Signs & Definition \\
\hline Dependent Variable & & & The ratio of net income/total assets \\
\hline Return on Asset & ROA & & $\begin{array}{c}\text { (Market Value of Equity + Total } \\
\text { Debt + Preferred Share)/Total Asset }\end{array}$ \\
\hline Tobin's Q & Tobin's Q & & \\
\hline $\begin{array}{l}\text { Independent } \\
\text { Variable }\end{array}$ & Firm Size & $+/-$ & $\begin{array}{c}\text { Natural Log of Total Asset } \\
\text { Firm Size }\end{array}$ \\
\hline Firm Age & Firm Age & $+/-$ & $\begin{array}{c}\text { Natural Log of Firm Age (difference } \\
\text { between the year of incorporation } \\
\text { and time t) }\end{array}$ \\
\hline Board Size & Board Size & $+/-$ & $\begin{array}{c}\text { Natural Log of Board Size } \\
\text { Diversity }\end{array}$ \\
\hline Leverage & $\begin{array}{c}\text { Diversity } \\
\text { Rebt to Asset }\end{array}$ & $+/-$ & $\begin{array}{c}\text { The proportion of female members } \\
\text { on Board }\end{array}$ \\
\hline
\end{tabular}

\section{Hypotheses}

Taking the theoretical arguments into consideration, the following hypothesis is proposed:

- $\mathrm{H}_{0}$ : Financial performance for pharmaceutical companies listed in DSE has not influenced gender-diverse boards of directors.

- $\mathrm{H}_{1}$ : Financial performance for pharmaceutical companies listed in DSE has influenced gender-diverse boards of directors.

\section{Model of the Study}

To investigate whether diversity on board affects firm's profitability, the model is used given below:

ROA $=\alpha+\beta 1$ Diversityit $+\beta 2$ FirmSizeit $+\beta 3$ FirmAgeit $+\beta 4$ BoardSizeit $+\beta 5$ Leverageit + cit Tobin's $\mathrm{Q}=\alpha+\beta 1$ Diversityit $+\beta 2$ FirmSizeit $+\beta 3$ FirmAgeit $+\beta 4$ BoardSizeit $+\beta 5$ Leverageit + cit 
Where $\mathrm{i}=1,2, \ldots \mathrm{n}$ and $\mathrm{t}=1,2, \ldots \mathrm{t}$ represent firm and a year respectively; $\beta$ is the parameter, and $\varepsilon$ represents the error term or disturbance

\section{Descriptive Statistics}

\section{EMPIRICAL RESULTS}

Descriptive statistics of all variables have been presented in the following table.

Table 2. Descriptive Statistics of Study

\begin{tabular}{|l|c|c|c|c|c|}
\hline Variable & Obs & Mean & Std. Dev. & Min & Max \\
\hline ROA & 216 & 0.0715 & 0.0972 & -0.4971 & 0.4402 \\
\hline MKt to Book & 216 & 4.8542 & 12.8614 & 0.0000 & 166.4684 \\
\hline TobinsQ & 216 & 1.8747 & 1.9446 & 0.0015 & 13.4145 \\
\hline Diversity & 216 & 0.2250 & 0.1810 & 0.0000 & 0.5714 \\
\hline Board Size & 216 & 1.9248 & 0.2551 & 1.3863 & 2.4849 \\
\hline Firm Size & 216 & 21.8397 & 1.5146 & 18.2006 & 24.8986 \\
\hline Firm Age & 216 & 3.2205 & 0.6691 & 0.6931 & 4.1744 \\
\hline $\begin{array}{l}\text { Debt Asset } \\
\text { Ratio }\end{array}$ & 216 & 0.2286 & 0.1947 & 0.0000 & 0.7034 \\
\hline
\end{tabular}

Source: Author's Calculation

In the following table, the comparison of the means for companies with or without women on boards of directors is shown. Based on the t-test results, it appears that there are no differences between the groups at 0.05 significant level. As all the values of the t-test stayed within the region on \pm 1.96 , we could not state that there is any difference between the groups.

Table 3. Comparison of the means

\begin{tabular}{|l|c|c|c|}
\hline & Average & Average & \\
\hline & $\begin{array}{c}\text { Companies with Female } \\
\text { Members on Board }\end{array}$ & $\begin{array}{c}\text { Companies without } \\
\text { Female Members on Board }\end{array}$ & T-test \\
\hline ROA & 0.0687 & 0.0780 & -1.4335 \\
\hline Tobin's Q & 2.1346 & 1.2574 & -0.0001 \\
\hline MKt to Book & 6.1724 & 1.7235 & 0.00003 \\
\hline Board Size & 1.9285 & 1.9158 & 0.0004 \\
\hline Firm's Age & 3.7480 & 3.7480 & 0.0000 \\
\hline Firm Size Asset & 21.8646 & 21.7805 & -0.00004 \\
\hline $\begin{array}{l}\text { Debt to Atio } \\
\text { Ratio }\end{array}$ & 0.2322 & 0.2200 & -0.0013 \\
\hline
\end{tabular}

Source: Author's Calculation 
Multicollinearity Test

Table 4. Results of VIF Test

\begin{tabular}{|l|c|c|}
\hline & VIF & 1/VIF \\
\hline Board Size & 1.15 & 0.8731 \\
\hline Firm's Age & 1.14 & 0.8759 \\
\hline Debt to Asset Ratio & 1.06 & 0.9411 \\
\hline Diversity & 1.04 & 0.9579 \\
\hline Firm's Age & 1.02 & 0.9775 \\
\hline Mean VIF & 1.08 & \\
\hline
\end{tabular}

Source: Author's Calculation

Here, none of the variables exceed 2.5 . If any variables exceeded 2.5 , a multicollinearity problem would have been spotted. Multicollinearity problem disturbs the individual effects of the independent variable on the dependent variable.

\section{Heteroscedasticity Test}

Model 1 shows no presence of heteroscedasticity, as Prob $>$ Chi2 is higher than .05, but the problem of heteroscedasticity is present in Model 2. This will need to be fixed. Homoscedasticity is one of the assumptions of the OLS (Ordinary Least Square) model.

Table 5. Results of Heteroscedasticity Test

\begin{tabular}{|l|c|c|c|}
\hline \multicolumn{4}{|c|}{ Breusch Pagan /Cook-Weisberg test for heteroscedasticity } \\
\hline \multicolumn{1}{|c|}{ Model } & Chi2(1) & Prob>Chi2 & Presence of Heteroscedasticity \\
\hline Model 1-ROA & 0.01 & 0.907 & NO \\
\hline $\begin{array}{l}\text { Model 2-Tobin's } \\
\text { Q }\end{array}$ & 55.87 & $0.000^{* * *}$ & YES \\
\hline
\end{tabular}

Note: * represents significance at $10 \%$ level, $* *$ represents significance at $5 \%$ level and $* * *$ represents significance at $1 \%$ level.

Source: Author's Calculation

\section{Autocorrelation Test}

Table 6. Results of Autocorrelation Test

\begin{tabular}{|l|c|c|c|}
\hline \multicolumn{4}{|c|}{ Wooldridge test for autocorrelation in panel data } \\
\hline \multicolumn{1}{|c|}{ Model } & F & Prob>F & Presence of Autocorrelation \\
\hline Model 1-ROA & 9.912 & 0.004 & YES \\
\hline Model 2-Tobins Q & 7.485 & 0.011 & YES \\
\hline
\end{tabular}

Note: $*$ represents significance at $10 \%$ level, $* *$ represents significance at $5 \%$ level and $* * *$ represents significance at $1 \%$ level.

Source: Author's Calculation

The Wooldridge test has been used in this study. The null hypothesis of the test states no autocorrelation. For both models, autocorrelation is present at a 0.05 significant level. The absence of autocorrelation is one of the assumptions of the OLS model. 


\section{Test for Cross-Sectional Dependency}

This is a crucial test to determine whether a Fixed-Effect or Random-Effect Model is enough to predict the relationship of variables or not. The null hypothesis is, there is no cross-sectional dependency among the panel. For Model 2, the null hypothesis has been rejected at 0.10 significant level Pesaran's value but can't be dismissed for Friedman's value. Thus, the average value of offdiagonal has been checked; it is higher than .25. So, there is the presence of cross-sectional dependency in this model. This needs to be considered while interpreting the data. The presence of cross-sectional dependence might lead to biased results from Fixed Effect or Random Effect model. Panel Corrected Standard Error (PCSE) Model should be used for a better result.

Table 7. Results of Test for Cross Sectional Dependency

\begin{tabular}{|c|c|c|c|c|c|c|}
\hline Model & $\begin{array}{c}\text { Pesaran's } \\
\text { value }\end{array}$ & P Value & $\begin{array}{c}\text { Friedman's } \\
\text { Value }\end{array}$ & P Value & $\begin{array}{c}\text { Avg. } \\
\text { value of } \\
\text { Off- } \\
\text { diagonal } \\
\text { elements } \\
\text { (abs) }\end{array}$ & $\begin{array}{c}\text { Cross- } \\
\text { Sectional } \\
\text { Dependency }\end{array}$ \\
\hline $\begin{array}{c}\text { Model 1- } \\
\text { ROA }\end{array}$ & -0.857 & 0.3917 & 4.074 & 1.0000 & 0.384 & NO \\
\hline $\begin{array}{c}\text { Model 2 } \\
\text { Tobin's } \\
\text { Q }\end{array}$ & 2.609 & 0.0091 & 17.840 & 0.8815 & 0.511 & YES \\
\hline
\end{tabular}

Source: Author's Calculation

\section{Hausman Test}

It is necessary to determine the model between the fixed and random effect models, which will better analyze the data. This is done via using Stata/MP 13 software and conducting Hausman Test. In this test, the null hypothesis is random effect model is appropriate.

Table 8. Results of Hausman Test

\begin{tabular}{|l|c|c|c|}
\hline \multicolumn{1}{|c|}{ Model } & Chi2(9) & P value & Decision \\
\hline Model 1-ROA & 10.04 & $0.0741^{*}$ & Fixed Effect Model \\
\hline Model 2-Tobins Q & 8.30 & 0.1405 & Random Effect Model \\
\hline
\end{tabular}

Note: $*$ represents significance at $10 \%$ level, $* *$ represents significance at $5 \%$ level and $* * *$ represents significance at $1 \%$ level.

Source: Author's Calculation

At Model 1, P-value is lower than the 0.10 level of significance; for this null hypothesis is rejected, the Fixed Effect Model is used to analyze data.

At Model 2, the P-value is higher than the 0.10 level of significance, for this null hypothesis is not rejected, and the Random Effect Model is used for this model. 


\section{Fixed Effect Model}

Table 9. Summary of Fixed Effect Model for Model 1

\begin{tabular}{|c|c|c|c|c|}
\hline Variables & Coef. & $\mathbf{t}$ & $\mathbf{P}>|\mathbf{t}|$ & Significance \\
\hline Diversity & 0.0525 & 0.4400 & 0.6620 & No \\
\hline Board Size & 0.0044 & 0.1000 & 0.9190 & No \\
\hline Firm's Age & 0.1816 & 2.1800 & $0.0300 * *$ & At 0.05 \\
\hline Debt to Asset Ratio & -0.1291 & -2.6700 & $0.0080 * * *$ & At 0.01 \\
\hline Firm Size & -0.0382 & -3.0100 & $0.0030 * * *$ & At 0.01 \\
\hline Constant & 0.2352 & 0.8600 & 0.3930 & \\
\hline R-Sq & \multicolumn{3}{|c|}{0.1167} & \\
\hline $\mathbf{F}$ & \multicolumn{3}{|c|}{4.86} & \\
\hline Prob $>F$ & \multicolumn{3}{|c|}{0.0003} & \\
\hline
\end{tabular}

Note: $*$ represents significance at $10 \%$ level, $* *$ represents significance at $5 \%$ level and $* * *$ represents significance at $1 \%$ level. (Underline) represents wrong sign.

Source: Author's Calculation

The table reflects the impact of the firm-specific accounting-based performance measure, ROA. The R-square value is $11.67 \%$, and P-value is less than 0.05 . The model is somewhat acceptable. The model shows diversity even though having a positive coefficient is insignificant. Among other variables, the Firm's Age is significant at 0.05, whereas, Debt to Asset Ratio and Firm Size are significant at 0.01 level. Even though Firm Size is significant, they are exhibiting the wrong sign.

\section{Random Effect Model}

Table 10. Summary of Random Effect Model for Model 2

\begin{tabular}{|c|c|c|c|c|}
\hline Variables & Coef. & $\mathbf{z}$ & \begin{tabular}{l|l|}
$\mathbf{P}>$ & $\mathbf{Z}$ \\
\end{tabular} & Significance \\
\hline Diversity & 1.7382 & 1.2800 & 0.2000 & No \\
\hline Board Size & 0.3516 & 0.5600 & 0.5750 & No \\
\hline Firm's Age & 7.7580 & 6.0800 & $0.0000 * * *$ & At 0.01 \\
\hline Debt to Asset Ratio & -0.7871 & -1.1000 & 0.2700 & No \\
\hline Firm Size & $\underline{-0.4184}$ & -2.6800 & $0.0070 * * *$ & At 0.01 \\
\hline Constant & 0.2352 & 0.8600 & 0.3930 & \\
\hline R-Sq & \multicolumn{3}{|c|}{0.1879} & \\
\hline Chi2 & \multicolumn{3}{|c|}{42.98} & \\
\hline Prob>Chi2 & \multicolumn{3}{|c|}{0.0000} & \\
\hline
\end{tabular}

Note: $*$ represents significance at $10 \%$ level, $* *$ represents significance at $5 \%$ level and $* * *$ represents significance at $1 \%$ level. (Underline) represents wrong sign.

Source: Author's Calculation

The table reflects the impact of firm-specific on a market-based performance measure, Tobin's Q. The R-square value is $18.79 \%$, and P-value is less than 0.05 . The model is somewhat 
acceptable. The model shows diversity even though having a positive coefficient is insignificant. Among other variables, the Debt to Asset Ratio and Firm Size are significant at 0.01 level. Even though Firm Size is significant, they are exhibiting the wrong sign.

Panel Corrected Standard Error (PCSE) Model

Table 11. Summary of Panel Corrected Standard Error (PCSE) Model for Model 2

\begin{tabular}{|l|c|c|c|c|}
\hline Variables & Coef. & $\mathbf{z}$ & $\mathbf{P}>\mid \mathbf{z}$ & Significance \\
\hline Diversity & 1.6566 & 2.3000 & $0.0210^{* *}$ & At 0.05 \\
\hline Board Size & 0.0855 & 0.1900 & 0.8490 & No \\
\hline Firm's Age & 6.3317 & 2.6900 & $0.0070^{* * *}$ & At 0.01 \\
\hline Debt to Asset Ratio & -0.4098 & -0.7800 & 0.4380 & No \\
\hline Firm Size & -0.4483 & -4.6300 & $0.0000^{* * *}$ & At 0.01 \\
\hline Constant & -12.7755 & -1.4400 & 0.1500 & \\
\hline R-Sq & \multicolumn{3}{|l|}{0.1755} & \\
\hline Chi2 & 30.4300 & \\
\hline Prob>Chi2 & \multicolumn{4}{|l}{0.0000} \\
\hline
\end{tabular}

Note: $*$ represents significance at $10 \%$ level, $* *$ represents significance at $5 \%$ level and $* * *$ represents significance at $1 \%$ level. (Underline) represents wrong sign.

Source: Author's Calculation

The table reflects the impact of firm-specific on a market-based performance measure, Tobin's Q. The R-square value is $17.55 \%$, and $\mathrm{P}$-value is less than 0.05 . This is an improvement from the random-effect model. In this model, diversity is positive and significant at 0.05 level. So, a 1 percent increase in variety on Board will cause a 1.66 percent increase in profitability. Among other variables, Firm Size and Firm Age is significant at 0.01 level. Even though Firm Size is significant, they are exhibiting the wrong sign.

\section{FINDINGS AND DISCUSSIONS}

Upon examining the effect of gender diversity in the Board of Directors, the current study found that diversity on the Board has positive effects on both ROA and Tobin's Q but significantly affects only Tobin's Q or the market measure of profitability. Tobin's Q includes the present and future outlook of the company. So, it seems that investors are somewhat optimistic due to the increase in diversity on Board, as this may result in more transparency and accountability. Board Size, even though positive, does not have any significant effect on profitability measures. It can be argued that board size has little to no impact on a firm's profitability.

Firm Age and Firm Size are statistically significant in both models, but the latter is exhibiting a theoretically wrong sign. So, high firm size will translate to high profitability cannot be stated for this study. The debt Asset ratio displays a theoretically correct sign in both models but is not significant for Model 2. 
Table 12. Comparison of two Models

\begin{tabular}{|c|c|c|c|c|c|}
\hline \multirow[t]{2}{*}{ Variable } & \multirow[t]{2}{*}{$\begin{array}{l}\text { Expected } \\
\text { Sign }\end{array}$} & \multicolumn{2}{|c|}{$\begin{array}{c}\text { Fixed Effect (Model } 1 \\
\text { ROA) }\end{array}$} & \multicolumn{2}{|c|}{$\begin{array}{c}\text { PCSE Model (Model } 2 \text { Tobin's } \\
\text { Q) }\end{array}$} \\
\hline & & $\begin{array}{l}\text { Actual } \\
\text { Sign }\end{array}$ & Significance & Actual Sign & Significance \\
\hline Diversity & $\begin{array}{l}\text { Positive/ } \\
\text { Negative }\end{array}$ & Positive & No & Positive & Yes \\
\hline Board Size & $\begin{array}{l}\text { Positive/ } \\
\text { Negative }\end{array}$ & Positive & No & Positive & No \\
\hline Firm's Age & $\begin{array}{l}\text { Positive/ } \\
\text { Negative }\end{array}$ & Positive & Yes & Positive & Yes \\
\hline Debt to Asset Ratio & Negative & Negative & Yes & Negative & No \\
\hline Firm Size & $\begin{array}{l}\text { Positive/ } \\
\text { Negative }\end{array}$ & Negative & Yes & Negative & Yes \\
\hline
\end{tabular}

\section{CONCLUSION AND IMPLICATIONS}

The Pharmaceutical Industry of Bangladesh presents the most significant white-collar job creation opportunity after the banking industry. In Bangladesh, though women's employment has been the talk of the town, women in decision-making is still a questionable issue. The study attempts to analyze the contribution of gender diversity among the Board of directors on the profitability of a firm in Bangladesh's pharmaceutical industry. With the help of a panel data approach, this study attempts to find the link with eight years of the sample period. Descriptive statistics, Multicollinearity test, Heteroscedasticity test, Autocorrelation test, Cross-Sectional Dependency tests, Regression Analysis, have been done to interpret the study. After analyzing, the PCSE model and Fixed effects models were chosen to interpret the data. For market measure, gender diversity's impact on Tobin's Q is significant, but gender diversity's impact on ROA is not significant for accounting measure. Hence, it can be stated that the inclusion of women on the Board can enhance the company's perception among the investors. This study can be a good source for investors, policymakers, and researchers to contend with and make viable decisions and policies to improve the performance of the firms.

This study incorporates only the listed companies of DSE. But to get a robust result and clearer outlook, further study needs to be conducted incorporating the companies that are not listed yet. So there is a scope of future investigation on this.

\section{AUTHOR CONTRIBUTIONS}

Conceptualization: Hossain Ahmmed Fahad

Data Curation: Imran Mahmud

Formal Analysis: Atkia Nabiha Rahman

Funding Acquisition: Hossain Ahmmed Fahad; Imran Mahmud; Atkia Nabiha Rahman

Project Administration: Hossain Ahmmed Fahad; Imran Mahmud

Software: Hossain Ahmmed Fahad; Imran Mahmud

Validation: Atkia Nabiha Rahman 
Writing - Original Draft: Hossain Ahmmed Fahad; Imran Mahmud

Writing - Review \& Editing: Hossain Ahmmed Fahad; Atkia Nabiha Rahman

\section{CONFLICT OF INTEREST STATEMENT}

The authors declare that they have no competing interests.

\section{ACKNOWLEDGEMENT}

All authors contributed equally to the conception and design of the study

\section{REFERENCES}

Adams, R. B., \& Ferreira, D. (2009). Women in the boardroom and their impact on governance and performance. Journal of Financial Economics, 94(2), 291-309. https://doi.org/10.1016/j.jfineco.2008.10.007

Asimakopoulus, I., Samitas, A., \& Papadogonas T. (2009). Firm-specific and economy wide determinants of firm profitability: Greek evidence using panel data. Managerial Finance, 35(11), 930-939.

Blažková, I., \& Dvouletý, O. (2019). Investigating the differences in entrepreneurial success through the firm-specific factors: Microeconomic evidence from the Czech food industry. Journal of Entrepreneurship in Emerging Economies, 11(2), 154-176.

Brown, D. A. H., Brown, D. L., \& Anastasopoulos, V. (2002). Women on boards: Not just the right thing...but the "bright" thing. The Conference Board of Canada. Retrieved from https://www.worldcat.org/title/women-on-boards-not-just-the-right-thing-but-the-brightthing/oclc/832335679?referer=di\&ht=edition\&fbclid=IwAR0QKUGiVZBvZmvHa6mIO SpVKRBinBcotlCsqftFThTq4NJ6PoCImIdLhak

Carter, D.A., Simkins, B.J., \& Simpson, W.G. (2003). Corporate governance, board diversity, and firm value. Finance Review, 38(1), 33-53.

Coad, A., Segarra A., \& Teruel M. (2013). Like milk or wine: Does firm performance improve with age? Structural Change and Economic Dynamics, 24(1), 173-189.

Erhardt, N.L., Werbel, J.D., \& Shrader, C.B. (2003). Board of director diversity and firm financial performance. Corp. Gov. Int. Rev., 11(2), 102-111.

Goddard, J., Tavakoli, M., John, O., \& Wilson, S. (2005). Determinants of profitability in European manufacturing and services: evidence from a dynamic panel model. Applied Financial Economics, 15(18), 1269-1282. https://doi.org/10.1080/09603100500387139

Gregory, I. S., Main, B. G. M., \& O'Reilly, C. A. (2014). Appointments, pay and performance in U.K. boardrooms by gender. The Economic Journal, 124(574), 109-128.

Haslam, S.A., Ryan, M.K., Kulich, C., Trojanowski, G., \& Atkins, C. (2010). Investing with Prejudice: The Relationship between Women's Presence on Company Boards and 
Objective and Subjective Measures of Company Performance, British Journal of Management, 21(2), 484-497.

Hambrick, D.C., \& Mason, P.A. (1984). Upper echelons: The organization as a reflection of its top managers. Academy of Management Review, 9(2), 193-206.

Huse, M. (2007). Boards, Governance and Value Creation: The Human Side of Corporate Governance. USA: Wiley.

Islam, M. (2018). Board diversity and firm's financial performance: A study on DSE listed pharmaceutical companies in Bangladesh. IOSR Journal of Business and Management, 20(12), 26-32.

Ionascu, M., Ionascu, I., Sacarin, M., \& Minu, M. (2018). Women on boards and financial performance: evidence from a European emerging market. Sustainability, 10(5), 1644, 118. https://doi.org/10.3390/su10051644

Jensen, M. C., \& Meckling, W. H. (1976). Theory of the firm: Managerial behavior, agency costs and ownership structure. Journal of Financial Economics, 3(4), 305-360.

Joy, L., Harvey, M., Wagner, Narayanan, S (2008). The Bottom Line: Corporate Performance and Women's Representation on Boards. Catalyst. Retrieved from https://www.catalyst.org/research/the-bottom-line-corporate-performance-and-womensrepresentation-onboards/?fbclid=IwAR2KJG8Qzm1CJUGrXF59rbiF_wfKSUbyescxsfXvzUuccKBWkeuh pbHzGEo

Kalsie, A., \& Shrivastav, S. (2016). Analysis of board size and firm performance: evidence from NSE companies using panel data approach. Indian Journal of Corporate Governance, 9(2), 148-172. https://doi.org/10.1177/0974686216666456

Lee, L. E., Marshall, R., Rallis, D., \& Moscardi, M. (2015). Women on boards: global trends in gender diversity on corporate boards. MSCI ESG Research, Inc. Retrieved from https://www.msci.com/documents/10199/04b6f646-d638-4878-9c61-4eb91748a82b

Luoma, P., \& Goodstein, J. (1999). Stakeholders and corporate boards: Institutional influences on board composition and structure. Academy of Management Journal, 42(5), 553-563.

Munira, S. (2020). Gender diversity in the boardroom and the firm financial performance of DSE listed companies in Bangladesh. Global Disclosure of Economics and Business, 9(2), 8996. https://doi.org/10.18034/gdeb.v9i2.513.

Meca, G., E., Sánchez, G., María, I., \& Ferrero, M., J. (2015). Board diversity and its effects on bank performance: An international analysis. Journal of Banking \& Finance, Elsevier, 53(C), 202-214. 
Nguyen, T., Locke, S., \& Reddy, K. (2015). Does boardroom gender diversity matter? Evidence from a transitional economy. International Review of Economics and Finance, 37, 184202. https://doi.org/10.1016/j.iref.2014.11.022

Nakatani, R. (2019). Firm performance and corporate finance in New Zealand. Applied Economics Letters, 26(13), 1118-1124.

Nunes, M. P. J., Serrasqueiro, Z. M., \& Sequeira, T. N. (2009). Profitability in Portuguese service industries: A panel data approach. Service Industries Journal, 29(5), 693-707.

Pratheepan, T. (2014). A panel data analysis of profitability determinants: Empirical results from Sri Lankan manufacturing companies. International Journal of Economics, Commerce and Management, 2(12), 1-9.

Rezina, S., Ashraf, A., \& Khan, M. A. (2020). An inferential study on the profitability determinants of the cement industry in Bangladesh. Asian Finance and Banking Review, 4(2), 8-21. https://doi.org/10.46281/asfbr.v4i2.684

Sá, T. M., Neves, E. D., \& Góis C. G. (2017). The influence of corporate governance on changes in risk following the global financial crisis: evidence from the Portuguese stock market. Journal of Management \& Governance, Springer; Accademia Italiana di Economia Aziendale (AIDEA), 21(4), 841-878.

Ujunwa, A. (2012). Board characteristics and the financial performance of Nigerian quoted firms. Corporate Governance (Bingley). 12(5), 656-674. https://doi.org/10.1108/14720701211275587

Vafaei, A., Ahmed, K., \& Mather, P. (2015), Board diversity and financial performance in the top 500 Australian firms. Australian Accounting Review, 75(25), 414-427.

\section{APPENDICES}

\section{Appendix A: List of Textile Companies}

\begin{tabular}{|c|c|c|c|}
\hline No. & Codes in DSE & No. & Codes in DSE \\
\hline $\mathbf{1}$ & ACI & $\mathbf{1 5}$ & JMISMDL \\
\hline $\mathbf{2}$ & ACIFORMULA & $\mathbf{1 6}$ & KEYACOSMET \\
\hline $\mathbf{3}$ & ACMELAB & $\mathbf{1 7}$ & KOHINOOR \\
\hline $\mathbf{4}$ & ACTIVEFINE & $\mathbf{1 8}$ & LIBRAINFU \\
\hline $\mathbf{5}$ & AFCAGRO & $\mathbf{1 9}$ & MARICO \\
\hline $\mathbf{6}$ & AMBEEPHA & $\mathbf{2 0}$ & ORIONINFU \\
\hline $\mathbf{7}$ & BEACONPHAR & $\mathbf{2 1}$ & PHARMAID \\
\hline $\mathbf{8}$ & BXPHARMA & $\mathbf{2 2}$ & RECKITTBEN \\
\hline $\mathbf{9}$ & BXSYNTH & $\mathbf{2 3}$ & RENATA \\
\hline $\mathbf{1 0}$ & CENTRALPHL & $\mathbf{2 4}$ & \\
\hline
\end{tabular}




\begin{tabular}{|l|c|c|c|}
\hline $\mathbf{1 1}$ & FARCHEM & $\mathbf{2 5}$ & SALVOCHEM \\
\hline $\mathbf{1 2}$ & GHCL & $\mathbf{2 6}$ & SQURPHARMA \\
\hline $\mathbf{1 3}$ & IBNSINA & $\mathbf{2 7}$ & WATACHEM \\
\hline $\mathbf{1 4}$ & IMAMBUTTON & & \\
\hline
\end{tabular}

\section{Copyrights}

Copyright for this article is retained by the author(s), with first publication rights granted to the journal. This is an open-access article distributed under the terms and conditions of the Creative Commons Attribution license (https://creativecommons.org/licenses/by/4.0). 